\title{
HERBACEOUS DIVERSITY OF K.A.H.M. UNITY WOMEN'S COLLEGE, MANJERI, KERALA, INDIA
}

\section{Fasna Sherin K}

Usman $A^{*}$

\author{
P.G. Department of Botany, K.A.H.M. Unity Women's College, Manjeri, \\ Malappuram, Kerala, India
}

P.G. Department of Botany, K.A.H.M. Unity Women's College, Manjeri, Malappuram, Kerala, India *Corresponding Author

\section{ABSTRACT}

The study was conducted at the Korambayil Ahamed Haji Memorial Unity Women's College, which is situated in the Manjeri Municipality of Malappuram district, Kerala State. The present study was aimed at determining the herbaceous plant species richness of the K.A.H.M.Unity women's college. For this, the species richness data was obtained by both secondary sources and intensive surveys from $2019-2020$. The data from the primary and secondary sources resulted in the documentation of 91 species of herbs belonging to 74 genera under 34 families. Out of 91 plants, 91 were Angiosperms. Among the angiosperms there were 64 dicots under 28 family and 27 monocots under 6 family. The contribution of dicotyledons was $70.32 \%$ and monocotyledons $29.67 \%$. Poaceae was the most dominant family with 12 species and 10 genera.The dominance of plants from Poaceae family in the study site, supports the harsh environmental conditions especially the water stress, because these plants have made morphological, anatomical and a physiological modifications to overcome the drought conditions. At present time, several of the important plant species are on verge of depletion, therefore such type of studies shall be paid serious attention for future prospects and to understand environmental conservation efforts. It also observed that successful strategies for management of useful species would be beneficial for future prospects.

\section{KEYWORDS : Manjeri, Herbaceous species richness, moist deciduous vegetation.}

\section{INTRODUCTION}

A nation's growth starts from its educational institutions, where the ecology is thought as a prime factor of development associated with environment. The green campus concept offers an institution the opportunity to take the lead in redefining its environmental culture and developing new paradigms by creating sustainable solutions to environmental, social and economic needs of the mankind (Sen \& Keshari, 2019). Appropriate conservative policies and sustainable development strategies are integral approach towards biodiversity. Biodiversity keeps the ecological processes in a balanced state, which is necessary for human survival (Kaur \& Sharma, 2014). As biodiversity equals variety at the species level of biological organization, the terms species richness and species diversity have become key concepts in conservation biology. The plant diversity at any site is influenced by species distribution and abundance patterns (Reddy et al., 2014). Both concepts are important characteristics of community structure. Therefore, much has been published on the measurement of the species richness and species diversity of communities (MacArthur, 1955; Hurlbert, 1971; Peet, 1974; Pielou, 1975; Magurran, 1988, 2004; Schluter \& Ricklefs, 1993; Colwell \& Coddington, 1994; Krebs, 1999). In the present work is designed with an objective to study the herbaceous diversity and documentation of campus flora.

\section{STUDY AREA}

Malappuram, one of the districts in Kerala, was formed in 1969. The geographical area of the district is $3,550 \mathrm{sq}$. $\mathrm{km}$. It is the third largest district of Kerala, as it occupies 9.13 per cent of the total area of the state. Manjeri is a town and municipality in Malappuram District in the state of Kerala with an extent of 53. sq. km out of the 7 taluks of Malappuram district. Manjeri is the headquarters of Ernad taluk. It is the second widest municipality in Kerala. The campus lies in $11^{\circ} 07^{\prime} 10^{\prime \prime}$ North latitude and $76^{\circ} 07^{\prime} 71^{\prime \prime}$ East longitudes. The terrain is laterite rocky. The characteristically hilly and undulating land is having an expanse of nearly 60 acres. The vegetation is a degraded moist-deciduous one. It was a barren hill at the time of inception of the college. Now the area is with plentiful trees planted by the nature clubs and other student community during the last three decades.

\section{METHODOLOGY}

The present study is the preliminary effort to collect and identify the Herbal Flora of K.A.H.M. Unity Women's college, Manjeri. The systematic collection of Herbs was made from various localities of college campus by visiting areas frequently. All mature, intact and undamaged herbal species were collected from college campus during the period from February 2019 to January 2020. The details were recorded in the field book and colour photographs were taken. Collected plant specimens were dried and preserved plants mounted on herbarium sheets by adhesive glue and fevicols. Identification of plants done with the help of Flora of the Presidency of Madras (Gamble, 1915-1936), Flora of British India (Hooker, 1872-1897), Flora of Malappuram (Babu, 1990), etc. Interactive CDs such as Flowering Plants of Kerala and Tree Identification Key prepared by Dr. N. Sasidharan of Kerala Forest Research Institute were also used for identifying specimens. Nomenclatural and phenologic details of the specimens were collected from these CDs. Photographs and herbaria of some unidentified specimens were sent to experts for confirming the identity.

\section{RESULTS \& DISCUSSION}

Herbaceous plant species are important components of ecosystems. Herbs are variable in their presence as well as presence of certain chemical compounds in their body system. The present study was aimed at assessing the herbaceous plant diversity. Total 91 plant species belonging to 34 families and 74 genera were recorded from the study site. Out of 91 plants, 91 were Angiosperms. Among the angiosperms there were 64 dicots under 28 family and 27 monocots under 6 family. The contribution of dicotyledons was $70.32 \%$ and monocotyledons $29.67 \%$. Poaceae was the most dominant family with 12 species and 10 genera.According to the abundance of herbaceous angiosperms in the campus, it has been observed that the Family Poaceae is most abundant followed by Asteraceae and Cyperaceae also shows wide range of vegetation in all over the area. At Genus level, Cyperus is largest with 4 species followed by Commelina and Lindernia with 3 species. Genus Eragrostis, Pennisetum, Phyllanthus, Mitracarpus, Sida, Euphorbia, Evolvulus, Cleome, Justicia and Asystasia with 2 species each. Remaining 61 genera are represented by only single species. 
Fig.l.Bar diagram showing the representation of the families.

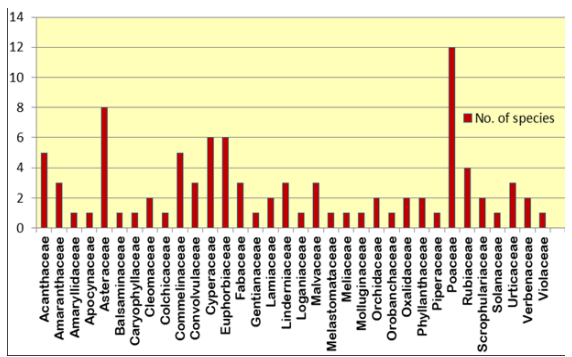

Table l. Showing dicot species richness.

\begin{tabular}{|c|c|}
\hline \multicolumn{2}{|c|}{ DICOTYLEDONS } \\
\hline Family & Plant species \\
\hline Acanthaceae & $\begin{array}{ll}\text { - } & \text { Asystasia dalzelliana } \\
\text { - } & \text { Asystasia gangetica } \\
\text { - } & \text { Justicia procumbens } \\
\text { - } & \text { Ruellia simplex } \\
\end{array}$ \\
\hline Amaranthaceae & $\begin{array}{ll}\text { - Achyranthus aspera } \\
\text { - Aerva lanata } \\
\text { - Alternanthera sessilis }\end{array}$ \\
\hline Apocynaceae & - Catharanthus pusillus \\
\hline Asteraceae & $\begin{array}{ll}\text { - } & \text { Ageratum conyzoides } \\
\text { - } & \text { Crassopidioides } \\
\text { - Eclipta alba } \\
\text { - Emilia sonchifolia } \\
\text { - Senecio vulgaris } \\
\text { - Synedrella nodiflora } \\
\text { - Tridax procumbens } \\
\text { - Vernonia cinerea }\end{array}$ \\
\hline Balsaminaceae & - Impatiens minor \\
\hline Caryophyllaceae & - Polycarpae corymbosa \\
\hline Cleomaceae & $\begin{array}{l}\text { - Cleome rutidosperma } \\
\text { - Cleome viscosa }\end{array}$ \\
\hline Convolvulaceae & \begin{tabular}{|ll} 
- & Evolvulus alsinoides \\
- & Evolvulus nummularius \\
- & Merremia tridentata \\
\end{tabular} \\
\hline Euphorbiaceae & 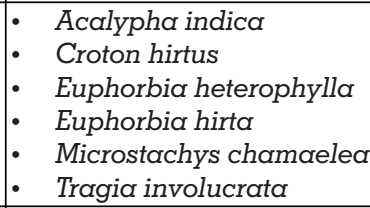 \\
\hline Fabaceae & 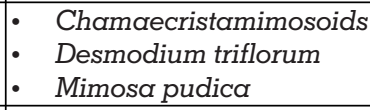 \\
\hline Gentianaceae & - Canscora pauciflora \\
\hline Lamiaceae & $\begin{array}{ll}\text { - } & \text { Hyptis suaveolens } \\
\text { - } & \text { Leucas aspera } \\
\end{array}$ \\
\hline Linderniaceae & 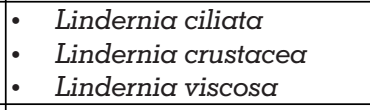 \\
\hline Loganiaceae & - $\quad$ Mitrasacme pygmaea \\
\hline Malvaceae & 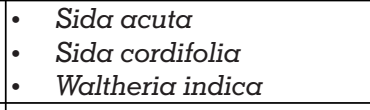 \\
\hline Melastomataceae & - Osbeckia muralis \\
\hline Meliaceae & - Naregamia alata \\
\hline Molluginaceae & - Mollugo pentaphylla \\
\hline Orobanchaceae & - Striga angustifolia \\
\hline Oxalidaceae & $\begin{array}{ll}\text { - } & \text { Biophytum sensitivum } \\
\text { - Oxalis corniculata }\end{array}$ \\
\hline Phyllanthaceae & $\begin{array}{ll}\text { - } & \text { Phyllanthus amarus } \\
\text { - } & \text { Phyllanthus virgatus } \\
\end{array}$ \\
\hline Piperaceae & - Peperomia pellucida \\
\hline
\end{tabular}

\begin{tabular}{|c|c|}
\hline Rubiaceae & $\begin{array}{ll}\text { - } & \text { Mitracarpus hirtus } \\
\text { - } & \text { Mitracarpus verticillatus } \\
\text { - } & \text { Oldenlandia corymbormacoce articularis } \\
\end{array}$ \\
\hline Scrophulariaceae & $\begin{array}{ll} & \text { Scoparia dulcis } \\
\text { - } & \text { Sopubia delphinifolia } \\
\end{array}$ \\
\hline Solanaceae & - $\quad$ Physalis minima \\
\hline Urticaceae & $\begin{array}{ll}\text { - } & \text { Pilea microphylla } \\
\text { - } & \text { Urtica parviflora } \\
\end{array}$ \\
\hline Verbenaceae & $\begin{array}{ll}\text { - } & \text { Priva cordifolia } \\
\text { - } & \text { Stachytarpheta indica } \\
\end{array}$ \\
\hline Violaceae & - Hybanthus enneaspermus \\
\hline
\end{tabular}

Table 2. Showing monocot species richness:

\begin{tabular}{|c|c|}
\hline \multicolumn{2}{|c|}{ MONOCOTYLEDONS } \\
\hline Family & Plant species \\
\hline Amaryllidaceae & - Hymenocallis littoralis \\
\hline Colchicaceae & - Gloriosa superba \\
\hline Commelinaceae & $\begin{array}{ll}\text { - } & \text { Aneilema nudiflorum } \\
\text { - } & \text { Commelina bengalensis } \\
\text { - } & \text { Commelina diffusa } \\
\text { - } & \text { Cyanotis cristata }\end{array}$ \\
\hline Cyperaceae & $\begin{array}{ll}- & \text { Cyperus longus } \\
\text { - } & \text { Cyperus paniceus } \\
\text { - } & \text { Cyperus rotundus } \\
\text { - } & \text { Fimberus sphacelatus } \\
\text { - } & \text { Kyllinga nemoralis ars } \\
\end{array}$ \\
\hline Orchidaceae & $\begin{array}{l}\text { - Habenaria grandiflora } \\
\text { - Zeuxine longilabris }\end{array}$ \\
\hline Poaceae & $\begin{array}{l}\text { - } \text { Dactylotenium aegyptium } \\
\text { - } \text { Eigitaria ciliaris } \\
\text { - Eragrochloa colona } \\
\text { - Eragrostis amabilis } \\
\text { - Oplismenus hirtellus } \\
\text { - Panicum repens } \\
\text { - Paspalum scorbiculatum } \\
\text { - Pennisetum pedicellatum } \\
\text { - } \text { Pennisetum polystachion } \\
\text { - Setaria pumila }\end{array}$ \\
\hline
\end{tabular}

Fig.2. Pie diagram showing herbaceous diversity of campus at Species, Genus, and Family level.

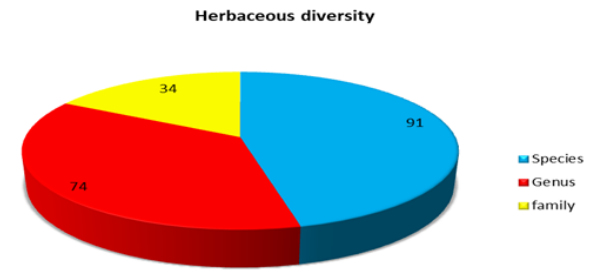

Fig. 3. Bar diagram showing Monocot and Dicot herbaceous diversity. Monocot \& Dicot herbaceous diversity - Family = $=$ Species $=$ Genus

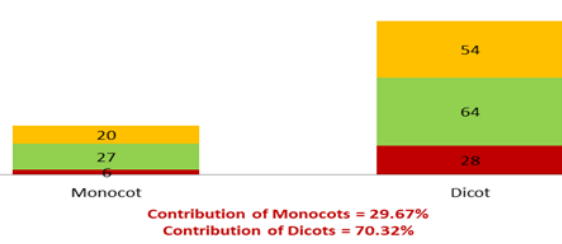

REFERENCES

1. Babu, A. (1990). Flora of Malappuram District (excluding Nilambur Forest Division). Parts I \& II, Ph. D. Thesis, University of Calicut, Calicut.

2. Colwell, R. K., \& Coddington, J.A. (1994). Estimating terrestrial biodiversity through extrapolation; Philos. Trans. R. Soc. London B 345 : 101-118. 
3. Gamble, J.S. \& Fischer, C.E.C. (1915- 1936). Flora of Presidency of Madras, Adlard \& Sons. Ltd., London.

4. Hooker, J.D. (1872-1897). The Flora of British India. Vols. I-VII, Reeve \& Co, Ltd., London.

5. Hurlbert, S.H. (1971). The non-concept of species diversity: A critique and alternative parameters. Ecology, 52, 577-586.

6. Kaur, K., \& Sharma, S. (2014). Diversity and Phytosociological Analysis of Tree Species in Sacred Groves of Vijaypur Block, Samba (J\&K). Int. J.Sc.\& Res., 6(3), 859-862.

7. Krebs, C. J. (1999). Ecological methodology (Menlo Park, CA: Addison Wesley Longman).

8. MacArthur, R.H. (1955). Fluctuations of animal populations, and a measure of community stability; Ecology, 36, 533-536.

9. Magurran, A.E. (1988). Ecological diversity and its measurement (Princeton, New Jersey: Princeton University Press).

10. Magurran, A. E. (2004). Measuring biological diversity. (Oxford: Blackwell)

11. Peet, R.K. (1974). The measurement of species diversity; Annual Review of Ecology and Sysematics, 5, 285-307.

12. Pielou, E.C. (1975). Ecological diversity. (New York: Wiley Inter science).

13. Reddy, B., Rao, V.H., Redy, V.B., \& Rao, V.V. (2014). Diversity and richness of herb species in peddagattu, the proposed site for uranium mining, Nalgonda district, Telangana state, India. Global Journal of Multidisciplinary Studies, 11(3), 197-204.

14. Sasidharan, N. (2012). Flowering Plants of Kerala - Version 2.0. DVD No. 14. Kerala Forest Research Institute, Peechi.

15. Schluter, D. \& Ricklefs, R. E. (1993). Species diversity: an introduction to the problem; in Species diversity in ecological communities: historical and geographical perspectives (eds) R. E. Ricklefs \& D. Schluter (Chicago: The University of Chicago Press).

16. Sen, M. \& Keshari, K.K. (2019). Green campus report. Directorate of Technical Education, l-4. 